\title{
総説論文
}

\section{体育科教育の課題 ${ }^{1}$}

\begin{abstract}
原 田 憲 一 (岐阜大学 $)^{2}$
\end{abstract}
Key words: [teach-learn] relation, a theory of humau body, a body of learner, a movement of leaner

キーワード：「教えるー学ぶ」関係, 身体論, 学習者の身体, 学習者の運動

\section{1.はじめに}

体育の現場では, 学習者が運動学習し, 教育 者が教えることである。その現象を整理し解明 するために, 種々の方面から研究がなされ, 体 育の現場に示唆を与えている，専門領域や基礎 学問を用いて体育現象を解明し，どれをとって みても必要かつ重要である。たとえば体育心理 学は, 体育の心理的側面, 特に学習者の心理を 探求するものであるが, 心理学という方法論を 用いて, 体育現象を探求する. 心理学の応用部 分であり, 心理学の一部でもある. 結局, 体育 の心理学的側面しか解明しない. 体育学研究 は, それぞれの研究分野からの探求であり, そ の方法も専門分野の方法に委ねられ，ほとんど が分割を試み，細分化して深化させている．雑 多な現象を素に分析し，より深化させ確実なも のの元へたどる方向はそれなりに意味がある.

そういった種々の側面からの研究が体育学の学 的体系をつくっていて，それらを統合して実践 が行われている，体育学は統合科学と言われて いるが，側面からの寄せ集めをいくらあげても 現実の現象のどの程度のことが理解できるのか
疑問が残る.もともと学術的研究は実利的なも のでなく，現象に具体化するためには，それな りの工夫と時間をさらに必要としている。しか しながら体育としての本質的問題や, 体育の現 場での理論は, 諸雑多な要因をすべて含めた化 合の方向がないと直接的にはなじまないものと なっている。

体育の教育内容となる運動についての探求も 必要であるが, 教育そのものは, 教育方法と内 容を含めた一つの行為である。確かに体育現場 からの運動や指導に関しての報告はいくつも紹 介されている. 臨床報告として興味深い意味の あるものだが，いまだ理論化には至っていない ようである。しかしながら体育の理論化は体育 実践の中からしか出てこないものではないだろ うか.

この小論は体育の実践において教育者が学習 者に運動を教えるにあたって, 難しいとされる その関係の仕方について, 実践の中から探求す るものである。体育哲学は体育現象を哲学とい う概念と方法論で探求するのが多く見られてい るが,ここでは体育という現象のなかに哲学的 問題が潜んでいるのではないか, 体育実践を整 
理することによって他では扱われていない哲学 的な問題に直面できるのではないかという試み である．換言すれば体育実践の整理と解決に向 けて, という課題の中での試みである.

方法に関していえば，体育をどのように理解 していくのかの問題ではあるが，体育現場に必 要なことは何なのかを体育の実践から考察し, 単純に問い直していくことである. 手順を示せ ば，佐藤のいう体育の関係概念と，瀧澤の運動 を主体から見る方法の身体論を参考にしなが ら，体育場面での具体的な実践を見ていくこと である。

\section{2. 体育の関係概念}

体育・スポーツ哲学会というこの学会の名称 もそうだが，体育・スポーッという捉え方に対 する問題がある。このことに関連して, 佐藤臣 彦は体育とスポーツを概念的に明確に区別して いないことを再三にわたって指摘している．体 育は教育概念であるがゆえに，「教える人と教 えられる人との関係性が思い浮かべなければな らない.」そして「体育が関係性を本質とする 教育概念であるのに対し，スポーツはそれ自体 の自立的構造をもった文化概念である．カテゴ リー論的には，体育が関係概念であるのに対 し，スポーツは実体概念で」両者は異なる位相 にあると指摘している，佐藤は最も基本的な問 題をいい当てている．体育とスポーツの問題は この区別をもって考えていかなければならな い. 体育の考察はこの関係性を抜きにしては成 り立たないし，本質的なところに近づくことは できない.

しかし佐藤のいう教える人と教えられる人と の関係とはどのような関係だろうか. 体育の現 場を見ると，それは単に「教える一教えられ る」関係ではない，先生は，「こういう運動を しなさい」と教えているのだが，学習者は先生 の指示や説明を聞きながら, 学習をしている。 決して先生の言いなりにすべてを鵜吞みに従っ
ているわけではない，示された運動を自分で理 解しょうとし，自分で判断し，自分でできる ように運動している。教えられるというより， 先生の教えられる内容を解釈し直して自分で 学習している。「教える一教えられる」という 関係ではなく，「教える一学ぶ」という関係で ある。

柄谷行人は規則を共有しない他者との非対称 的な関係にコミュニケーションを見出そうとし た.ヴィトゲンシュタインが言語に関して「教 える」という視点から考察しているのに対し， 柄谷はそこから，他者性・関係性などを問題と して展開している。コミュニケーションを同じ 共同体の中ではなく，共同体と共同体の間に見 ようとした. すなわち共通の規則を持たないも のに教えるということである。言葉のまだ知ら ない赫ちゃんに言葉を教える場合や，日本語を 知らない外国人に，日本語で日本語を教えるこ とを想起すれば理解できる。「教える一学ぶ」 という関係は，非対称の関係である．さらに柄 谷は，同一の規則を持つ対話の方が例外的で, それは自分と同一の者との対話，すなわち自己 対話を規範として考えている，自己対話，ある いは自分と同じ規則を共有する者との対話は, 対話ではなく独自である，対話は，自分の規則 と共有しないものを持つ者とのことであって， その者との関係は非対称である。柄谷は, 対 話そのものが, この「教える一学ぶ」関係だと いう。

教育とは知識を持っているものが, 知識を 持っていないものに教えること，「先生が教え る，学習者が学ぶ」という関係である，先生が 自分自身の主張や独白をするのであれば，学習 者に教える教育ではなく，それはもはや独我論 となってしまう。先生と学習者たちは，「教え るー学ぶ」という関係が, 成り立たなくてはな らない。

教育の中で，最近よくいわれていることだ が，自己教育という概念がある，目標として自 
分ひとりで学習できる能力を身につけることを 目指していることだと解釈できるが，教育その ものは, 決して学習者が「独りで学ぶ」ことで はない. 教育は先生と学習者たちとの関係, つ まり佐藤のいう教える人と教えられる人との関 係での行為である。

教えることは，基本的には或る価値の方向へ 導くことである，そのためには，教育を大きく 解釈すれば直接的行為だけでなく, 規則や環境 の整備もすべてであって，その方法・教え方も 種々である，共同体内部に作られた規則は外部 から見れば不可解であっても，その共同体の内 部で生存するには従わなければならない. 強制 的な訓練もその一つの方法であり得る. だから 支配, 服従という関係も教育の一部分であり, そういった関係の仕方もあることは解釈上成り 立つことである。しかし教育は基本的に管理や 支配とは異なる。だから権力関係と混同しては ならない. 例えば, その時, 赤ん坊に対して支 配者であるよりも，その奴隷であることは明白 である，赤ん坊は言葉を全く知らないのだから 知らなくて当然である. 教える側は, 決して優 位にあるのではない，逆に，学ぶ側の合意を必 要とし，その恣意に従属せざるを得ない弱い立 場にある。

学習者が知識や技術を獲得することは, 学習 することであって，教育だけが知識を獲得する すべではない。あらゆる情報を取り入れて, 理 解しなおすこと, 納得することである. 生存す ること自体, 環境を把握し, 他人を意識し, 自 分自身を省みたりしながら，特別に意識しなく ても学習しているといえる，そのように考える と, 学習や思考は基本的には単独で成り立つも のである，それを他の人との関係で確認しなが ら自分自身で確信し，より確害に，またより普 遍化するためにすることである。

学習と教育は異なる概念である，学習してい る学習者に対して先生がいかに学習しやすくす るかどうかの関係をつくることである．学習者
は学校で先生に教えてもらうという構図のようた が, 実際には学校は学習者が学ぶところである。

\section{3. 瀧澤の身体論}

瀧澤文雄は現象学を用い体育における重要な 概念である身体について探求している，身体運 動を解明するに当たって，まず身体を明らかに しなければならないとして身体の解明から始め る。その際身体運動を用いることによって身体 が鮮明に見えてくるという体育の方法論的独自 性と固有の問題を含ませている。その身体の考 察のなかで, 客観的な自然科学的な身体の見方 が実際に運動をすることにどれほど役に立つの かという現実的問題に疑問を投げかけ，身体を 主体の側から見る見方を提起する。同じ対象で あっても視点や見方を变えると違って見えてく るのは当然である。身体や身体運動を自然科学 的尺度を借りて客観的に外側から見るのではな く, 連動者主体から見るという方法である。自 然科学がとっているように客観的な数字や記号 あるいは言語にも置き換えることではできな い. 運動者の身体そのものもから見る見方であ るから, 理解の仕方も論理的な理解ではなく全 体をいわば体験そのものを身体が理解している ことである．澈澤はそれらを客観的に見る見方 から得られる言語的な思考が優先されることと 混乱を避けるために，独自の概念を定めて論を 展開している。そして身体の賢さという概念を 提出し, 身体の構造を見出し, 身体そのものの 解明に向かっていく。

生命体は世界のなかで生存するのに安定した 関係の仕方を身体に持っている，身体は世界を 見る視座としての存在の仕方である。したがっ て通常の意識は外部の世界に対してであって, 自分の身体について意識することはない。しか しながら人間は何らかのきっかけで自分の身体 を意識することもできる，通常通りに世界を見 ることが困難になったとき，つまり世界との関 係が今までと同じ関係でなく違和となったと 
きつまり身体の異常や通常でない運動をしよ うとしたとき等が顕著である．具体的には脚を 怪我していつものように歩けなくなったときを 想起すれば理解できる，澈澤が言う本来「地」 としての身体が突如「図」となったときであ る。それは身体が世界を見る視座を持ちながら 意識を自分の身体に向けるという見方で眺めて いる.

瀧澤の考察の中で身体の潜性という概念があ る. 身体の経験の蓄積のことを言っているもの だと理解できる．同じ世界であっても身体に備 わった経験によってその世界の把握の仕方が異 なる. 他の人との違い, 同一人物であっても成 長や経験の異なった過去と現在の違いなどもこ の概念で整理される，運動ができる人とできな い人など身体の持っているものの違いによって 世界との関係の仕方つまり身体の世界の見え方 が異なっている.

運動者自身の運動を主体から見るといっても 単に主観的に見るのではない. 瀧澤のいう主体 から見ると言った場合, 運動者主体の身体から 見るのであって，単に主観的に見ることを言っ ているのではない. 言語的な思考ではなく, 非 言語的な知として了解することも言っている が，身体自身が思考し，身体全体が了解するこ とである．たとえ自分の身体や運動を意識的に 自覚することが出来なくても，身体が了解して いることは多くある．私たちは生存する世界の 気候等の自然環境，身体の不快や飢えや渴きな どを意識することが出来るが，生命体の維持レ ベルでも他の動物と同じように身体が了解して いる.

しかし，そのなかで感じのかたまりとして捉 えることもその一つである. 本来は身体が世界 を把握しているのだが，身体全体から捉えたこ とを自覚的に対象化し, 頭の中で分節して認識 レベルで了解することも可能である. 受容器が 明確でないので感覚と呼ぶに值するのか不明だ が, 身体全体で感じるとしか言いようのない捉
え方がある．筋感覚や平衡感覚また内臟や生理 からくる感覚あるいは心的な気分などあいまい な感じのかたまりとしてとらえている。

その感じのかたまりが真にいい当てているか どうかはそれこそ判断中止しなければならない 事柄である，たとえ同じ現象であっても，他の 人と感じ方は当然違っているが，同一人であっ ても, 身体の潜性の問題もあって, 感じのかた まりも違ってくる。しかしさまざまであって も，たとえ間違いであっても，その状況におい て自身の身体を通じてそのように感じ，そのよ うに捉えていることだけは確かなことである.

\section{4. 運 動}

体育で学習している運動やスポーツ運動での 運動課題は外的なものがほとんどである. 他者 や外界の状況との関係において, 身体の動作で 身体やものを操作することができるかというも のである、スポーツにおいては選手自身や選手 の身体の特徵を問題にしないで結果としての運 動の出来栄えを比べ競争するのが通常である. そういう意味では主体の側からとらえた運動で はなく運動を外的に捉えている. 事実, 人間の 運動は一つの客観でもある. だから運動学は自 然科学的分析で身体運動を客観的に探求するの が主流となっている.

同じ客観としての運動であっても運動する人 が変われば運動者主体にとっての捉え方は異な る. 同じ運動課題を達成するのに100パーセン トの力が必要な人と50パーセントの力で課題を 達成できる人もいる，走り高跳びで同じ高さを 跳ぶ場合，身長の高い人と低い人ではどうだろ う.同じ運動でも主体がどのように捉えるかの 違いがある，例えば短距離走で腕を前後に強く 振る動作を行う場合，おそらく腕を前と後の両 方を意識することはしないだろう。意識の焦点 化をして，前に焦点を持っていくか後に焦点を 持っていくかのどちらかである.

瀧澤の方法論で運動者から見る必要がありそ 
うである，身体を運動者主体から見るという方 法に従って運動を運動者主体からみてみればど のようになるだろうか.ところが運動を運動者 主体から見ても自分の運動は見えない。運動は 身体の運動である，身体は世界を見る視座であ るから，自分自身の運動であっても身体は視座 となって自分の身体ではなく外部を把握して世 界と関係づけている。自分の運動つまり身体は 見えなくて，世界の外界を見ることが一般的で ある．運動者は運動をどのように把握している のかと問うとすれば，運動者が運動をするとき 世界をどのように見ているのか，を問うことに なるかもしれない.

本来の運動は習慣化されていて, 意識的な操 作はほとんど必要としない. 向こうへ行こうと 思っただけで歩くことは出来る．階段がここに あることを知覚しただけで，階段登行ができ る、外界を知覚するだけでいわば反射のように 無意識でも動くことができる，スポーツ運動も 特にそうである，自分自身の身体や動かし方を 意識しなくても動くことができる．外界をどの ように把握するかだけである，ところがうまく 運動ができないときは自分の身体に気づく，疲 れてきたときに脚が重くなって無意識では動か なくなった時，今まで「地」であった身体が 「図」になって，初めて自分の身体に気がつ く、そして脚を意識して力を入れたりして, 今 までとは違って意識的に脚を動かそうとする。

スポーツ運動など日常生活でない運動をして いるときは通常とは異なった世界の捉え方をし ているといえる，運動を通した世界との関係の 仕方で, 身体が運動という形式で世界と関係付 けている. 運動の環境, 使用するもの, 時間な ど, 本来客観的であるものを主体的な独特の捉 え方をしている，運動がうまくできたときとそ うでないときとを比べると明白である，運動が できるときは状況やもの・相手を詳細にまた独 特の見え方をしているのが何よりの証拠であ る、たとえばできるだけ遠くへ投げたり，より
高く遠くへ跳んだりする運動の場合，客観的に は大きな力が必要なのだが，うまくできないと きは重たく感じ，うまくできたときは力量感は ない.

スポーツ選手が試合での運動を語る内容はそ の運動ができない者にとっては信じられない作 り話のように聞こえるときがある。しかしス ポーツ選手が語ることは，嘘でなければ，その ように知覚し，認識したからこそその運動を選 択して実施しているのである。それが単なる主 観で，客観的には正しいとは言い切れなかった としても，その運動が成立している事実があ る，選手が運動をする根拠は，その運動中に捉 えていることに求めている．但しその捉えた内 容が正しいかどうかではない. 問題はそれが正 しいかどうかではなく，運動の根拠にしている ことである。

運動を学習する学習者がまだうまく運動がで きない段階は運動をどのように捉えているのだ ろうか. 種々な層があって一概にはいえない が，おそらく運動を熟知した人とは異なった見 え方をしている。また運動の習熟の度合いに よっても異なっているはずである，うまく運動 ができない場合や偶然的にできた運動などの場 合は，自分の身体がどうなっているのかはまっ たく見えていない.それらしくできている運動 や注意すればできる運動の段階は自分の身体が 思うように動かなかったり，身体や運動の夕イ ミングなどに焦点を集めて意識したりして自分 の身体や運動を捉えている。しかし習熟すると 運動や身体は地となって背景に退き，運動の場 としての世界を認識するので，自分の運動は自 動化され見えにくくしている.

瀧澤は身体の潜性から, 運動に関して, 動作 に対する「下位動作」という概念を提起してい る.ある一つの動作はいくつかの下位の動作が 合成されたものであるという，例えば歩くとい う動作には立つという姿勢や一方の足を前に出 すという下位の動作がある．また一方の足を前 
に出すという動作には反対の足で体重を支えて 立つという下位の動作がある，運動を生起させ るにはそのような身体の構造があるとことを明 示している，反対にある動作ができないという ことは，下位動作の組み合わせがうまく結合し ないか，あるいは動作に必要な下位動作を持っ ていないからということになる.

運動者が無意識的に無自覚のままで何気なく いわば反射的に動作を起こしても，また意識的 に身体を駆使して巧みな動作をしても，自分の 身体は動ける身体を持っていることは身体がそ の動作を理解し，知っていることになる。

\section{6. 運動の知}

佐藤は, 経験知より学問的な理論知の方がよ りいっそう知的であるとし, 運動に必要な経験 知を開かれた知のレベルへ引き上げることが必 要だという。そしてその可能性も大いにあると いっている.

運動実践が学問であるかどうふ，と問えば当 然学問ではない. 理論知と経験知では位相が異 なる．それを同じ概念で捉えることが出来るの かどうかを考えなければならない. 理論知とい えどもすべてが同じ水準にはない.

例をあげる．校内で社会科の授業で全校研究 会があったときのことであるが，「はっきりし た事実から提示すべきだ.」と理科の先生の発 言があった．社会科学と自然科学では事実とい う概念が異なっていた.

ここで吟味していることは，動くために必要 なものは何かである．動ける身体は何を持って いるのか, 動く時には何を根拠に動くことがで きるのかである.

運動体験で得た理解，たとえば「この運動は このようにすればできる」とか，「このように 感じたときはこうすればいい」というような感 じやコッのようなものは, 客観的な知にはなり えない. その感じそのものが正誤を問うもので はない. 判断中止しなければならことなのであ
る。しかしその感じを根拠に運動が成立してい ることは事実であり，そういう水準では真であ る。ましてや運動者が自覚できない身体自身が 持っているものなど理論知などといえるもので はないのは明白である.

他の教科を学習するときはどうだろうか. 数 学なり物理なり客観的な知識を理解しようとし ているのだが, 学習者が理解した知識とは客観 的知識であるのだろうか. 理解していること が，その知識が客観的知識と一致しているかど うかは確かめることが出来るだろうか.

中学校の数学の図形の授業で見た光景の例を あげる．分かった子は分からない子に教えてあ げることを通して自分の理解をさらに深めると いう授業であった.「ここが平行だから，ここ とここの角が同位角で等しいから，この三角形 とこの三角形は相似である。云々」と説明して もらうが, 分からないという. 2 回目は鉛筆で なぞりながら繰り返し同じ説明を聞いていて, 分からなかった子が顔を晴らして「分かった」 という。そして同じょうにして今度はその子が 他の人に説明をするものであった。聞いた説明 を分らない時に復唱しても，分かってから人に 説明する時も同じ文言であった。

子どもが理解した知識は, 少なくとも先生が 理解している知識と同じではない。だからすべ ての例題を解くことはできない. 理解した知識 は単なる主観ではないが, その知識といわれる ものは学習者の理解である.

運動では技術と技能でよく似たことが言われ ている，技術は客観的のもので，人の運動から 取り出して対象化することが出来る. 人が動くと きは技術を駆使したその人の技能となっている.

ここで明確にしておかねばならないのは，動 けるための根拠にするものは客観的な知ではな いことである。

\section{7. 学 習}

運動学習は片岡が言うように運動という形式 
を使った身体と世界との関係の改善である，運 動学習の場合, 身体の存在する外界である環境 の変化と身体自身の変化, さらにその関係の変 化を要求する，運動の環境を変えることも可能 だし，環境に身体を適応させることもありう る.しかし一般的な方法は新たに身体の運動に かかわる構造を改築するのを目指すことになる。

自分自身の身体の構造を変化させるために は，身体で真似ること，なぞることを基本と し, 何回も何回も繰り返して学習することが必 要である．環境と身体との関係を習慣化させ定 着させて，身体の構造化を図るのである，しか し効率よく学習するには, 意識的な操作も必要 である．自覚的な部分，つまり主体から身体を 自覚的に変更させる意図が必要である，ところ が自然科学的な外的に対象化した客観的データ のままではあまり役に立たない．客観的デー夕 や客観的知識は自分自身の身体で翻訳して, 感 じとして主体的に捉えなおす必要がある。その 翻訳した感じが正しいかどうかは別の問題であ るが, いわば感覚的に捕らえる事がかなり有効 である。それには確かな信や根拠がなければ不 安に陥ることも生じかねない. 学習を効果的に 進めていくためには, 内在的動機付けの持続も 必要である。そのためには目標が必要だし, 進 歩の度合いが知りえた方がよりよいことも多 い. 直接的な運動課題だけではなく他の情報を 取り入れたり, 下位動作の獲得や, 類似の運動 も必要だろう。新しく運動を習得するには, 運 動ができないときとは違った身体になるわけだ から，自分で気がつかないことや今までの身体 にはない世界を得るための工夫も必要だろう。 一人で学習するならばそのことも自分自身で行 わなければならない．とにかく自分の身体で手 がかりが必要なところである.

\section{8. 子ども (学習者) の運動}

子どもの運動をよく観察すると様々なところ で，考えさせる現象に出会う. 子どもが運動を
どのように捕らえているのか, 運動していると きに何を見ているのかを推測するのに非常に参 考になる場合がある．次にいくつか例をあげる．

小学校低学年の子どもがボールを捕る時に次 のようなことを観察した．自分の方ではなくて 他の方向へ転がっていくボールを走っていって 捕ろうとしたとき，ボールが転がって行く方向 へ走り出すのではなく, 今現在ボールのある所 に向かって走り出す．ボールが転がっているの でその都度ボールの転がっているところへ徐々 に追いかけることになって, やがてボールを 真っ直ぐ追いかけることになった.

バスケットボールやサッカーのボールゲーム では，とにかくボールしか見えていない。ボー ルだけを追いかけてボールの方へ走り出す. ボールを持ったときは自分の目の前の相手しか 見えなくて, 走り出す方向もパスを出す方向も 見えていない. だから子どものボールゲームを 見るといつもボールのところにみんなが集まっ て密集になる，そのとき味方のチームの人がど こにいるのか, 空いているスペースがあるのか は見えていない.

ハードル走で，ハードリングの跳び越す練習 を踏み切る方向も跳ぶスピードや抜き脚と振り 下ろし脚のスピードも脚の操作も部分に分けて 練習するとできるのだが，実際にスピードをつ けて走って跳びこそうとするとそれができな い. 部分の動作を忘れているのか, 全体の運動 として統合できないのか, 恐怖や不安によって 出来なくなっているのか, とにかく上に跳んで しまうことがある。

短距離走では, 小学生の低学年子どもはある 程度自然な走り方を持っている，中学生になっ てくると特に女の子は子どものころの自然な走 り方はなくなっている子が目立つ. 絶対的ス ピードは中学生のほうが速いのだが, 短距離走 の動作としてはむしろ悪くなっていて，体格と 年齢に比べれば速く走れない子が増えている. 小学生は全力疾走するとよく転ぶ. 中学生は転 
体育・スポーツ哲学研究. 29-2（2007）

ばない.おそらく何回も転ぶことによって, 速 く走るには不合理でも転ばない安定した走り方 を身につけてしまうのだろう，自分で意識的に 学習しているわけではなく, 自分でも気がつか ないうちに身体のレベルで獲得しているものと 考えられる。

運動ではないが，子どもが運動をどのように 捉えているか伺える例がある. 小学校低学年の クラスで子どもが鉄棒の絵を描いたのを教室に 掲示してあるのを見たことがある．鉄棒を握っ ている子どもの握りこぶしがやたら大きく描か れているのが何枚かあった. どうみてもアンバ ランスであった. 子どもの絵が自分の運動中の 意識であるのか, 運動の印象や記憶を思い出し ているのか, 運動を見た印象か不明であるが, 描いた絵には握りこぶしが強調されていた。

運動を観察することによって，運動者の身体 は，運動中に何を根拠に運動をしているのか, 運動中の自分の身体や相手, 物, 環境をどのよ うに身体が把握し，どのように認識しているの か，見抜けるといい.

\section{9.「教える一学ぶ」関係}

教育は教育的価值に向かって被教育者を高め ることである．教育者側の意図的計画的な行為 であるが，被教育者が学習するのを容易にする ための支援である．だからその関係は「教え るー学ぶ」であるといった。この「教えるー学 ぶ」関係が成り立つのは可能か. 共有の規則を 持たないものにどうしてコミュニケーションが 成り立つのか. 柄谷はそれを「暗闇の中での跳 躍」「命がけの飛躍」の後にすぎないと言う. この跳躍はその都度盲目的, 恣意的であって, 神秘である. 要するに計算不可能で, 確実な方 法はないのかもしれない.

赤ん坊に支配されること, 即ち, 自分の規則 ではなく，相手側の規則に基づかなくてはなら ない. 先ず相手側の規則を知らなくてはならな い. 先生が, 学習者の世界を知り得ることがで
きるのか. 学習者の世界の中へ入り込むことが できるのか.もちろん相手側にもこちら側の規 則に近づく努力は必要なわけであるが, 結局の ところ, 盲目的, 恣意的であり, 神秘である. 教育を実践していく中で，「教えるー学ぶ」 という関係を考えてみれば，私たちがいえるこ とは，学習者の世界に近づく努力のみである. たとえ言葉が何とか通じるからといっても, 言 葉で運動の内実を伝えることができない，身体 的存在としての学習者は, 身体が異なる. 持っ ている身体の構造, そこから派生する心情や理 解は異なっていて，人それぞれが固有である. 運動ができない人の世界を知ること，学習者か ら見た運動・身体の世界を知ろうとすること， つまり運動のできない身体は何が分かってい て，何が分からないのか, どのように感じてい るのかを知ることである. そして少しでも共通 の規則に近づくことである。そうすることに よって身近な関係を作らなければならない。 近づくことができれば，学習者の身体が知り える変更可能な範囲での指摘, 学習者の状況に 応じて学習者の身体に対応した精密な援助が出 せることが可能となる．動けない身体が必要と している適切で精密な指摘を提起することがで き，学習者の身体に役立つはずである．それは 下位動作や身体のことばかりではないはずであ る、時には恐怖や不安を取り除く自信や，でき そうな予感や見通しなど心的な要素も含まれて いる. その指摘や助言が学習者の学習の手がか りとなり, 学習者か効率よく学習していけるこ とになる。

「教えるー学ぶ」関係を新たに作ることは恣 意的であるが，その関係を作ることが教育だと すれば, 先生は運動の出来ない身体, 学習者の 世界を知る努力である。

\section{文 献}

片岡暁夫 体育原理とは何か 体育原理講義 大修館書店 1987，12-21. 
柄谷行人 探求 I 講談社 1986 .

原田憲一 運動すると何が生じるか，「運動の 知性的意味を探る (1)」, 体育原理研究, 第28号, 151-155, 1998.

原田憲一・藤田忠久 体育の目標としての「感

じ」について, 岐皁大学教育学部研究報告

(自然科学)，第25巻第 2 号，33-41，2001.
スポーツと超能力，日本教文社， 1984 .

佐藤臣彦 体育学の対象と学的基礎 体育学研 究 1999, 14-6, 483-492.

佐藤臣彦 身体教育を科学する 北樹出版 1993. 澈澤文雄 身体の論理 不昧堂出版 1990 . 瀧澤文雄 実践的能力としての「からだ」の賢 さ 体育学研究 1998, 43-2, 79-90. M. マーフィー・R. A.ホワイト・山田和子訳, 